\title{
"DANZARE PER FANTASMATA», OR THE EMBODIMENT OF THE IMMATERIAL IN FIFTEENTH-CENTURY ITALIAN DANCE DISCOURSE
}

\author{
Alessandro ArCangeli \\ Università degli Studi di Verona (Italia) \\ alessandro.arcangeli@univr.it
}

The expression I intend to comment on occurs, with variations, in two well-known fifteenth-century Italian texts on court dancing. It represents an example of particularly obscure language within works that have in general posed interpretative challenges to scholars. I will start from introducing it descriptively and contextually; I will subsequently proceed to expose and discuss a selection of particularly significant critical responses it has elicited over the past thirty-five years; I will provisionally conclude my remarks with a few suggestions for further consideration.

1. The writer of the earliest extant fifteenth-century treatise De la arte di ballare et danzare, the Urtext of a whole textual tradition, Domenico da Piacenza, knowingly listed six key elements of his art: misura, memoria, agilità, maniera, misura del terreno and «fantasmata». At least since the pioneering work of Michael Baxandall, art history has been familiar with these categories too and has explored the connections they may have had with the conceptualization and representation of bodily movement and spatial disposition in Renaissance art and art criticism ${ }^{1}$. It would be difficult, however, to avoid the sensation that the last element I have mentioned is the most enigmatic one. It is peculiar to Domenico, although Antonio Cornazzano reuses it in a

${ }^{1}$ Michael Baxandall, Giotto and the Orators: humanist observers of painting in Italy and the discovery of pictorial composition, Oxford, Clarendon Press, 1971, pp. 11-13; Sharon Elizabeth Fermor, «Studies in the Depiction of the Moving Figure in Italian Renaissance Art, Art Criticism and Dance Theory», unpublished DPhil diss., London, Warburg Institute, 1990, esp. pp. 46-47. 
variant form (ombra fantasmatica), which in the peculiarity of its reformulation leaves us wondering what he really made of his source.

Let us start with the original text.

As Domenico puts it,

chi del mestiero vole imparare bisogna danzare per fantasmata. E nota che fantasmata è una presteza corporalle, la quale è mossa cum lo intelecto de la mexura dicta imprima di sopra, facendo requia a cadauno tempo, che pari haver veduto lo capo di Meduxa, como dice el Poeta, cioè che facto el motto sii tutto di piedra in quello instante et in instante mitti ale como falcone che per paiça mosso sia².

The figure of Medusa and the story of her beheading by Perseus was known to medieval culture via a wealth of classical texts including Ovid's Metamorphoses (from 1497 also printed in the Italian translation by Giovanni Bonsignore, which however dated from the fourteenth century); it also developed into an iconographic tradition, both ancient and post-classical (down to Benvenuto Cellini's mid-sixteenth-century statue). Attempts to suggest symbolic interpretations of the myth also date back to Antiquity: it would be fascinating to be able to assess the range of connotations it may offer to a fifteenth-century audience ${ }^{3}$; however, it may prove quite hard for specific cultural contexts, and it is safer to assume that the simile simply suggested, via a vivid image with literary resonances for the educated, a process comparable to petrification (sii tutto di piedra). As we will soon see, the interpretive tradition of this passage has had more to say about its implied dynamics.

2. If we consider the role the reappreciation of Antiquity played in Renaissance culture, and the presence of classical terms in Domenico's text, it is intriguing to compare his fantasmata with Greek schemata (a term that also designated geometric shapes). The study of ancient iconography has shown how much music and dance influenced the meaning socially attributed to a set of poses, as well as the games of simulation and dissimulation that were made possible by the sharing of cultural connotations of postures and gestures: in classical Athens, as attested by Aristotle (Poetics, 1477a), in dance

${ }^{2}$ Domenico da Piacenza, De arte saltandi et choreas ducendi, Bibliothèque nationale de France, ms. f. ital. 972, c. 2r; cfr. Patrizia Procopio, $I l$ De arte saltandi et choreas ducendi di Domenico da Piacenza. Edizione e commento, Ravenna, Longo, 2014, p. 78.

${ }^{3}$ For the treatment of the story and the allegorical interpretations provided by the most influential sixteenth-century mythographer, see Natale Conti's Mythologiae, trans. and annotated by John Mulryan and Steven Brown, 2 vols., Tempe, Arizona Center for Medieval and Renaissance Studies, 2006, pp. 634-637. 
and painting alike, such poses were believed to allow performers to mimic characters, emotions and actions ${ }^{4}$. Could the individual poses enacted by the Renaissance dancer also be charged with recognizable meanings?

Despite such potential resonances, it would appear unlikely that a northern Italian dancing master (that is to say, not even connected with the Greek world via the Byzantine tradition of the South) would have knowledge of a long gone performing experience. My critical remarks in this direction are only meant to suggest intriguing parallels - similarities themselves are only hypothetical - not quite derivations.

3. From the 1970s, after early research on historical dances aimed at recovering the experience of their actual performance had made some inroad, the path was open for cultural historians with wider interests in the period to borrow information from dance historians and choreographers and make use of it in imaginative ways, thus offering contributions towards a historical anthropology of the human body. Rudolf zur Lippe, an intellectual coming from the Frankfurt School, did so within a personal interpretation of the late Renaissance as the locus of a major shift in self-perception and demeanour. From this perspective, Domenico's passage (cited, with challenging intertextuality, next to Hegel's Phenomenology of Mind) exemplifies the free and open-ended dance aesthetics of the Quattrocento prior to the subsequent geometrization and disciplining of the Cartesian body ${ }^{5}$.

In a move of explicit distancing from the work of the reconstructionists, Mark Franko, the next scholar who discussed the passage extensively (regardless the fact that he is also a choreographer and a dancer) intended his analysis of Renaissance and baroque texts as a contribution towards a history and philosophy of the body. In observing that zur Lippe excessively identifies fantasmata with the pose, the North American interpreter emphasises Domenico's specific positioning of what he calls fantasmata between movement and pause (or better, pose), to be followed by a sudden return to movement (in such a rapid way to suggest, after quasi-petrification, the new striking image of the flight of a bird of prey). More precisely:

${ }^{4}$ Maria Luisa Catoni, Schemata. Comunicazione non verbale nella Grecia antica, Pisa, Edizioni della Normale, 2005; repr. La comunicazione non verbale nella Grecia antica, Torino, Bollati Boringhieri, 2008.

${ }^{5}$ Rudolf zur Lippe, Vom Leib zum Körper. Naturbeherrschung am Menschen in der Renaissance [1974], Rowohlt, Reinbek bei Hamburg, 1988, pp. 103-104. On the differences between Rudolf zur Lippe and his source, dance historian Ingrid Brainard, see Patrizia Procopio, «"Danzare per fantasmata”. L'immagine del movimento nell'arte coreutica del primo Rinascimento», in Bruniana \& Campanelliana, 16:2 (2010), pp. $559-568$ (p. 562). 
[...] fantasmata is not a quality peculiar to either movement or the pose, but rather one inherent to their interplay. [...] Fantasmata denotes movement as the phantom of itself, about to stop but not yet stasis. It also designates the pose as the transition from statue to animation. [...] Fantasmata [...] defines dancing as a compromise between movement and the pose, a transitional act in which each seems about to become the other. The pose is animated from within, and movement carries the body from one tonic pose to another ${ }^{6}$.

The Italian philosopher Giorgio Agamben has returned to the topic on a rather unusual occasion, for dance studies standards. He did so in 2007 within his Ninfe, a short book published by Bollati Boringhieri within their Incipit series. Agamben's study is concerned with human memory and imagination, and conducted via a close reading of Aby Warburg's notion of Pathosformel and its application in the Mnemosyne atlas, cross-referenced with a variety of cultural citations from a diverse palette of figures and experiences in Western intellectual history, in an absorbing conceptual tour de force. Whatever the way the philosopher happened to encounter it, the role played in his argumentation by Domenico's notion of fantasmata is significant, placed as it is in a quasi-initial position, thus guiding the reader, via a rhetorically strategic step, into the Warburghian analysis of the working of time, motion and performance in human experience. Agamben quotes our familiar passage from the fifteenth-century treatise and relates it to the Aristotelian theory of memory. According to the Greek philosopher - who developed the point in a short treatise On Memory and Reminiscence, highly influential on medieval and Renaissance psychology - an image (phantasma) is an affect (pathos), which modifies the body and may trouble those minds that are unable to order it; only those beings who are capable of perceiving time can remember, by the use of imagination.

To assign to a dancing master such a historical role in a complex investigation on the operating of the human body and mind is a bold interpretative gesture, one which dance scholarship has hesitated in making. Or rather, the terrain of a conflict of interpretations between scholars who have tended to play up or down the degree of interaction Renaissance dance may have entertained with the humanist project. As one may expect, scholars who have given it significant importance, such as Alessandro Pontremoli, have subsequently welcomed Agamben's contribution for the new insights it could offer on the meaning of the experience of the Renaissance performative arts.

${ }^{6}$ Mark Franko, The Dancing Body in Renaissance Choreography (c. 1416-1589), Birmingham, AL, 1986; Id., «The Notion of "Fantasmata" in Fifteenth-Century Italian Dance Treatises», in Dance Research Annual, 16 (1987), pp. 68-86 (quotation from pp. 77, 79). 
The result is a new emphasis on the importance of our concept: as the Italian colleague puts it, «il danzare per fantasmata è la condizione di memorabilità della danza stessa» ${ }^{7}$.

How familiar Domenico may have been with detailed philosophical knowledge, or whether, as Pontremoli has it, his whole writing can be effectively interpreted as an exercise in scholastic argumentation, is not easy to establish. The fact remains that fragments of a Greek philosophical lexicon and explicit references to the Philosopher par excellence are there, scattered, and cannot be ignored while attempting an analysis of the author's concepts and of their likely contexts and meanings.

4. What would Domenico, what would his direct interlocutors, his intended and actual readers and followers think of when speaking of phantoms? What would that imply in their representation and understanding of the experience of the dancer and of his or her audience? Together with the philosophical tradition, is this choice of vocabulary introducing some level of reference to ideas of ghosts and ghost-like experiences of visual perception and memory ${ }^{8}$ ? (Do ghosts dance, a part from North American indigenous ones?) And if so, in what way may such linguistic connotations affect an aesthetic theory that has listed this keyword among those defining the art of courtly dancing as a whole?

Aristotle and his subsequent interpreters provided the medieval and Renaissance tradition with a standard description of the process of perception and memory based on an interaction between human faculties. While we are all very familiar with the senses on one hand and the intellectual and rational power on the other, it may perhaps be worth reminding that this traditional assessment of human psychology also identified a third function, imaginatio

${ }^{7}$ Alessandro Pontremoli, Danza e Rinascimento, Macerata, Ephemeria, 2011, pp. 54-56 (quotation from 55). See also Patrizia Castelli, Il moto aristotelico e la licita scientia. Guglielmo Ebreo e la speculazione sulla danza nel XV secolo, in Mesura et arte del danzare. Guglielmo da Pesaro e la danza nelle corti italiane del $\mathrm{XV}$ secolo, ed. by Patrizia Castelli, Maurizio Mingardi and Maurizio Padovan, Pesaro, Pucelle, 1987, pp. 35-44; Jennifer Nevile, The Eloquent Body. Dance and Humanist Culture in Fifteenth-Century Italy, Bloomington, Indiana University Press, 2004, ad indicem; Annalisa Sacchi, «"Il privilegio di essere ricordata". Su alcune strategie di coreutica memoriale», in Ricordanze, ed. by Susanne Franco and Marina Nordera, Torino, UTET, 2010, pp. 107-122; Procopio, art. cit.; Id., Il De arte saltandi, pp. 136-137; Elisa Anzellotti, «Fantasmata: l'astanza della danza?», in Danza e ricerca. Laboratorio di studi, scritture, visioni, 7:8 (2016), pp. 47-62.

${ }^{8}$ Cornazzano's rephrasing and his reference to shadows (ombra) may point in this direction, though it does not testify to the author's understanding of Domenico's aesthetic point - namely, the dialectics of movement and pose. Cfr. Alessandro Pontremoli and Patrizia La Rocca, Il ballare lombardo. Teoria e prassi coreutica nella festa di corte del XV secolo, Milano, Vita e Pensiero, 1987, p. 96; Procopio, art. cit., p. 566. 
or phantasia, which played an indispensable role of go-between in conjunction with the other two. The word phantasma, specifically, had been used by Plato with predominant reference to reflections in mirrors or pools. Aristotle, instead, reserves it for appearances in the psyche, sometimes describing it as being analogous to paintings or wax impressions ${ }^{9}$. In Aristotelian terms, therefore, phantasmata play an integral part in the physiology of perception, as well as offering material for mental images that can subsequently fuel memory, dreams, thought and action. As an object of phantasia, a phantasma was a representation of a perceptible object, which presented the advantages (as well as the risks, non being necessarily veridical) of being available to our experience even in the absence of the actual object. To adopt this vocabulary within (humanist) dance discourse, if we can consider it sufficiently calculated, would have suggested in Domenico an implicit reference to a discrete (rather than continuous) series of poses of the dancer as playing a significant role in the perception and later remembrance of a given choreography, presumably both on the part of the performer and on that of their viewers.

5. The study of the appearance of ghosts - whether in the experience of dreams or on that of wakeful visions - and of the beliefs concerning them is a fascinating page of cultural history, one which Jean-Claude Schmitt has reconstructed with his customary brilliancy for the medieval millennium, and the terrain of further research by other scholars. It tells us the story of the relations between the living and the dead. Among other points, Schmitt defines ghosts as those who resist the social necessity of forgetting (if we acknowledge that the collective memory of the dead also worked as une technique social d'oubli): thus, their appearance is a significant feature in individual and collective memory, even if it may be considered as an exception to the rule. While the early Christian Church tended to treat beliefs on the return of the dead as superstitious pagan heritage, the Middle Ages registered a significant shift, witnessed by the recurring of the theme in miracle narratives and sermons ${ }^{10}$. It would be tempting, from here, to follow a line exploring the

\footnotetext{
${ }^{9}$ Nigel J. T. Thomas, «Mental Imagery», in The Stanford Encyclopedia of Philosophy [1997] (Fall 2014 Edition), ed. by Edward N. Zalta. [Online]. URL: <https://plato.stanford.edu/archives/fall2014/entries/mental-imagery/> [Consulted: 20/3/2017]; Deborah Modrak, «Aristotle on Phantasia», in The Routledge Handbook of Philosophy of Imagination, ed. by Amy Kind, London, Routledge, 2016, pp. 15-26. I thank Margherita Arcangeli for the above references. Cfr. also De la phantasia à l'imagination, sous la dir. de Danielle Lories et Laura Rizzerio, Louvain, Peeters, 2003.

${ }^{10}$ Jean-Claude Schmitt, Les Revenants: Les vivants e les morts dans la société médiévale, Paris, Gallimard, 1994 (Eng. transl. Ghosts in the Middle Ages, Chicago, University of Chicago Press, 1999). Schmitt dates the birth of the Western phantom, «that of cartoons and of fantastic films», at the end of the thirteenth century (Revenants, pp. 239-243; Ghosts, pp. 210-213). See also Claude Lecouteux, La
} 
connection of this experience with the topos of the dance of death and the custom of dancing in cemeteries; however, this would take us a few steps too far from the limited scope of re-examining a text produced, after all, within the specific community of the Italian Renaissance court environment. Such reticence from over-interpreting the potential cultural connotations does not prevent us from considering ways in which reference to ghost-like experiences are likely to have been used and understood in contemporary culture and society, how likely they may be to have made a vivid impression in people's imagination and thus left an indelible stamp on their memory ${ }^{11}$.

Memoria is in fact another of Domenico's category, and classical mnemotechnics attributed central role precisely to images and to the power they exerted on human imagination as vehicles for remembering anything associated to them. Beside any other aesthetic significance, as ghost-like postures fantasmata would have served Renaissance dancers to remember their step sequences, as well as allowed their viewers to grasp a narrative constructed by the film-like juxtaposition of a series of photograms - an analogy already suggested within Mark Franko's insightful reading ${ }^{12}$.

Recibido: 23/03/2017

Aceptado: $15 / 05 / 2017$

maison et ses génies: Croyances d'hier et d'aujourd'hui, Paris, Imago, 2000 (Eng. trans. The Tradition of Household Spirits, Rochester, VT, Inner Traditions, 2013); Darren Oldridge, Strange Histories, London, Routledge, 2004.

${ }^{11}$ Pontremoli and La Rocca (Il ballare lombardo, p. 97) intepret the passage as follows: «Si tratta di una sorta di virtuosismo interpretativo, di artificio drammatico acquistato per "acidentia", che consiste nel danzare come se ad un tratto si avesse l'apparizione di un fantasma e si dovesse riprodurre, di conseguenza, la fissità allibita del proprio stupore».

${ }^{12}$ Franko, «The Notion of 'Fantasmata'», art. cit., p. 79. 


\title{
$\cos$
}

\author{
«DANZARE PER FANTASMATA», OR THE EMBODIMENT OF THE IMMATERIAL \\ in Fifteenth-Century Italian Dance Discourse
}

\begin{abstract}
AвSTRACT: Within fifteenth-century Italian texts on court dancing we encounter the fairly elusive expression «danzare per fantasmata». It has been connected with the powers of the imagination and the techniques of memory, in relation to both the performers and their audiences. It seems suggestive of some ghost-like experience. It is introduced in the key source, Domenico da Piacenza, with extraordinary images, suggestive of a moment of absolute stillness, soon followed by a swift flight. The relevance of this stylistic category on Renaissance dance aesthetics has undergone recent re-evaluation; so would deserve its implications for the time and space perceptions of dancers and onlookers alike.
\end{abstract}

Keywords: Fantasmata. Domenico da Piacenza. Pose. Memory.

\section{«DANZARE PER FANTASMATA», O LA CONCRECIÓN DE LO INMATERIAL EN EL DISCURSO ITALIANO SOBRE LA DANZA EN EL SIGLO XV}

RESUMEN: En los textos italianos del siglo xv sobre el baile en la corte se encuentra la expresión, bastante evasiva de «danzare per fantasmata». Ésta, ha sido conectada con la fuerza de la imaginación y las técnicas de la memoria, en relación tanto con los artistas como con sus audiencias; parece además sugerir una especie de experiencia visionaria. La expresión se introduce en una obra clave de Domenico da Piacenza, y cuenta con extraordinarias imágenes descriptivas de un momento de absoluta quietud, seguido por un rápido vuelo. La relevancia de esta categoría estilística en la estética de la danza renacentista ha sido recientemente reconsiderada por la crítica; por lo que la misma atención se tendría que prestar también a sus implicaciones con la percepción del tiempo y del espacio de los bailarines y de los espectadores.

Palabras clave: Fantasmata. Domenico da Piacenza. Pose. Memoria. 